ISSN 0258-7122

Bangladesh J. Agril. Res. 36(3) : 507-512, September 2011

\title{
SELECTION IN SEGREGATING POPULATION OF TOMATO (Solanum lycopersicum) FOR GROWTH, YIELD AND VIRUS RESISTANCE
}

\author{
M. S. ISLAM ${ }^{1}$, S. AHMAD ${ }^{2}$ AND M. A. HOQUE ${ }^{3}$
}

\begin{abstract}
Nineteen segregating lines of tomato were evaluated at the Horticulture Research Centre of BARI during winter season of 2008-2009 with a view to developing high yielding virus resistant varieties. Wide variation was observed among the lines in respect of number of fruits per plant (13.5-38.3), individual fruit weight (56.8-162.3g), fruit yield per plant $(1.28-2.40 \mathrm{~kg})$, and locule number of fruit (2.0-8.5). The highest number of fruits per plant was observed in the line 14-1-1-1-1, but its corresponding individual fruit weight was only 58.4g. The line 15-3-4-2-1 had the highest individual fruit weight (162.3g). The highest fruit yield was recorded from the line 15-3-4-2-1 (81.6 t/ha), which was closely followed by the line 15-1-2-2-1 (79.5 t/ha). Thirteen genotypes were found free from virus infection up to 60 days after transplanting, while the rest had very low (1.4 - 2.8\%) virus incidence. Among the entries, considering yield and virus reaction, the lines, 8-1-3-4-1, 8-1-3-1-1, 8-1-3-2-2, 14-1-1-1-1, 15-3-4-2-1, 151-2-2-1 and 15-1- 2-1-2 were selected for further evaluation and recommendation as varieties.
\end{abstract}

Keywords: Segregating population, tomato.

\section{Introduction}

Tomato (Solanum lycopersicum) is a widely grown vegetable crop in the world. It is recognized as good source of vitamins and minerals. Per unit yield of tomato in Bangladesh is very low compared to that in other Asian countries. Among the production constraints, pest and disease incidence, adverse climatic conditions, absence of high yielding varieties are the most important ones. One of the most serious diseases of tomato is tomato yellow leaf curl virus (TYLCV) caused by a Gemini virus transmitted by Bemisia tabaci. Losses due to this disease can reach up to $80 \%$ (Nakla and Maxwell, 1998). Several methods have been developed to control TYLCV disease, such as use of healthy transplants, cultural management, chemical control of the vector, crop rotation, breeding for resistance, etc. (Muqit, 2006). However, the most effective and environmentally sound management remains in the planting of resistant or tolerant varieties (Kasrawi et al., 1988). Thus breeding for TYLCV resistance is probably the most important long term goal for durable management of TYLCV. In this regard, Asian Vegetable Research and Development Centre (AVRDC) initiated research on effective TYLCV resistance breeding and to identify sources of resistance through traditional and molecular breeding approaches (AVRDC, 1998). Olericulture

1,2\&3 Senior Scientific Officer, Principal Scientific Officer, and Director, respectively, Horticulture Research Centre (HRC), Bangladesh Agricultural Research Institute, (BARI), Gazipur, Bangladesh. 
Division of HRC, BARI collected nine TYLCV resistance segregating tomato lines from AVRDC, Taiwan in 2005 with a view to developing high yielding and TYLCV tolerant/resistant varieties under Bangladesh condition through selection from the segregating generations.

\section{Materials and Method}

Nine segregating tomato lines were collected from Asian Vegetable Research and Development Centre, Taiwan in the year of 2005 with a view to developing high yielding virus free tomato varieties through individual plant selection. Nineteen lines were selected for preliminary yield trial after four generations of selection from segregating populations (Anon., 2007; Anon., 2008). The seeds of 19 lines were sown on 30 September and seedlings were transplanted in the main field on 11 November 2008. The experiment was laid out in RCB design with three replications. The unit plot size was $4.8 \mathrm{~m} \times 1.0 \mathrm{~m}$. The plants were spaced at 60 $\mathrm{cm} \times 40 \mathrm{~cm}$. The crop was fertilized with 10 tons of cowdung, 550kg urea, 450 $\mathrm{kg}$ TSP, and $250 \mathrm{~kg}$ MP per hectare. Half of cowdung, entire TSP, and half of MP were applied during land preparation. The remaining half of the cowdung was applied during pit preparation. The rest of MP and urea were applied in three equal installments at 15, 30, and 45 days after transplanting. Irrigation, pruning, mulching, weeding, etc. were done as and when necessary. Ten plants were selected randomly from each replication for data collection on yield and yield attributes. TSS was determined by hand refractometer. Firmness was examined by hand of the ripened fruit. Virus incidence was recorded at 30, 45, and 60 DAT considering whole plant population of each replication through rigorous field observation. The compiled data were statistically analyzed for interpretation of results. The simple correlation coefficient was worked out according to Panse and Sukhatme (1967).

\section{Results and Discussion}

Yield and yield contributing characters of selected 19 lines grown during the winter season of 2008-2009 are presented in Table 1. Higher estimates of range, co-efficient of variation, standard deviation for all the parameters indicating the presence of variability among the lines suggested a wide scope of selection for desired line(s). Days to 50\% flower ranged from 60-72 days. However, most of the lines flowered in between 60 and 65 days. Plant height varied from 91.7 to $136.0 \mathrm{~cm}$. Number of fruits per plant also differed among the lines. The highest number of fruits per plant was recorded from the line 14-1-1-1-1 (38.3), but its corresponding individual fruit weight was very low (58.4 g) compared to that of other lines. Individual fruit weight ranged from 56.8 to $162.3 \mathrm{~g}$ indicating the presence of smaller and bigger fruit bearing lines. Seven lines had more than $130 \mathrm{~g}$ of individual fruit weight. These materials would be precious for future breeding programs to enhance individual fruit weight since most of the BARI 
Table 1. Performances and virus infection of 19 segregating tomato lines.

\begin{tabular}{|c|c|c|c|c|c|c|c|c|c|c|c|c|}
\hline \multirow{2}{*}{ Genotypes } & \multirow{2}{*}{$\begin{array}{c}\text { Days } \\
\text { to } 50 \% \\
\text { flower }\end{array}$} & \multirow{2}{*}{$\begin{array}{l}\text { Plant } \\
\text { height } \\
(\mathrm{cm})\end{array}$} & \multirow{2}{*}{$\begin{array}{l}\text { No. of } \\
\text { fruits/ } \\
\text { plant }\end{array}$} & \multirow{2}{*}{$\begin{array}{c}\text { Individual } \\
\text { fruit wt } \\
\text { (g) }\end{array}$} & \multirow{2}{*}{$\begin{array}{c}\text { Fruit } \\
\text { length } \\
(\mathrm{cm})\end{array}$} & \multirow{2}{*}{$\begin{array}{c}\text { Fruit } \\
\text { breadth } \\
(\mathrm{cm})\end{array}$} & \multirow{2}{*}{\begin{tabular}{|c|} 
Fruit \\
yield/ plant \\
$(\mathrm{kg})$
\end{tabular}} & \multirow{2}{*}{$\begin{array}{l}\text { Yield } \\
\text { (t/ha) }\end{array}$} & \multirow{2}{*}{$\begin{array}{l}\text { TSS } \\
(\%)\end{array}$} & \multicolumn{3}{|c|}{ Virus infection (\%) (DAT) } \\
\hline & & & & & & & & & & 30 & 45 & 60 \\
\hline $12-5-3-6-1$ & 64 & 104.73cd & $24.5 b-d$ & $60.21 \mathrm{~m}$ & 5.50a-d & 5.19d-f & $1.4 \mathrm{ab}$ & 47.6ab & 3.2 & 0 & 0 & 0 \\
\hline $12-5-3-3-1$ & 60 & $107.0 \mathrm{~cd}$ & 22.6b-e & 61.51 & 5.23b-e & 5.18d-f & $1.34 \mathrm{ab}$ & $45.56 \mathrm{ab}$ & 3.3 & 0 & 0 & 0 \\
\hline $12-1-1-3-1$ & 66 & $130.6 a$ & 23.8b-e & $56.8 \mathrm{~m}$ & 5.48a-d & $6.4 \mathrm{bc}$ & $1.28 \mathrm{~b}$ & $43.52 b$ & 3.2 & 0 & 0 & 0 \\
\hline $12-5-1-1-1$ & 60 & 128.lab & $26.3 \mathrm{bc}$ & $65.7 \mathrm{k}$ & $4.71 \mathrm{e}$ & $5.41 \mathrm{~d}-\mathrm{f}$ & 1.69ab & $57.46 \mathrm{ab}$ & 3.2 & 1.4 & 1.4 & 1.4 \\
\hline $8-1-3-4-2$ & 62 & $112.7 \mathrm{bc}$ & 14.0de & $125.2 \mathrm{f}$ & $5.45 a-d$ & $7.47 \mathrm{a}$ & $1.7 \mathrm{ab}$ & $57.8 \mathrm{ab}$ & 3.35 & 0 & 0 & 0 \\
\hline $8-1-3-2-1$ & 62 & $94.2 \mathrm{~d}$ & 13.5e & $138.3 c$ & $5.94 a$ & 7.31a & 1.78ab & $60.52 \mathrm{ab}$ & 3.36 & 1.4 & 1.4 & 1.4 \\
\hline $8-1-3-1-1$ & 60 & $103.5 \mathrm{~cd}$ & $15.8 \mathrm{c}-\mathrm{e}$ & $135.4 \mathrm{~cd}$ & $5.93 a$ & 7.0lab & 2.02ab & 68.68ab & 3.3 & 0 & 0 & 0 \\
\hline $8-1-3-2-2$ & 60 & 103.7cd & 14.8de & $146.3 b$ & 5.75a-c & 7.18ab & 2.03ab & 69.02ab & 3.28 & 0 & 0 & 0 \\
\hline $9-2-1-2-1$ & 64 & $100.6 \mathrm{~cd}$ & 22.2b-e & 80.6j & $6.02 \mathrm{a}$ & $5.08 \mathrm{ef}$ & $1.75 \mathrm{ab}$ & 59.5ab & 3.2 & 0 & 0 & 0 \\
\hline $14-1-1-1-1$ & 61 & 97.6cd & $38.3 a$ & $58.41 \mathrm{~m}$ & 5.54a-d & $4.88 \mathrm{f}$ & 2.2th & 74.8ab & 3.17 & 1.4 & 1.4 & 2.8 \\
\hline $15-1-2-1-1$ & 64 & 123.0th & $16.5 c-e$ & $124.6 \mathrm{f}$ & $6.04 \mathrm{a}$ & 6.93ab & 1.96ab & 66.64ab & 3.36 & 0 & 0 & 0 \\
\hline $15-1-2-2-1$ & 64 & $136.0 \mathrm{a}$ & 18.3cde & 131.6e & 5.82ab & 7.23a & 2.34ab & 79.56ab & 3.18 & 14 & 2.8 & 2.8 \\
\hline $15-1-2-1-2$ & 64 & 123.0th & 16.2de & 132.4de & $5.94 a$ & 7.06ab & $2.08 a b$ & 70.72ab & 3.21 & 1.4 & 1.4 & 2.8 \\
\hline $15-3-4-6-1$ & 72 & $91.7 \mathrm{~d}$ & $18.5 c-e$ & $84.5 \mathrm{i}$ & 5.04de & 5.77c-e & 1.49ab & $50.66 \mathrm{ab}$ & 3.08 & 0 & 0 & 0 \\
\hline F-test & ns & $* *$ & $* *$ & $* *$ & $* *$ & ** & $* *$ & ** & ns & NA & NA & NA \\
\hline CV (\%) & 4.89 & 7.83 & 12.06 & 15.61 & 5.34 & 15.05 & 18.24 & 18.24 & 3.27 & & & \\
\hline
\end{tabular}

Means followed by same letter(s) in a column do not differ significantly at $1 \%$ level of probability by DMRT,

Ns $=$ Not significant, $* *=$ Significant at $1 \%$ level, NA= Not analyzed. 
released tomato varieties have smaller fruit size (Rashid et al., 2006). The highest fruit yield per plant was observed in the line 15-3-4-2-1 (2.4 kg) closely followed by $15-1-2-2-1(2.34 \mathrm{~kg})$. Besides, five other lines produced more than $2.0 \mathrm{~kg}$ of fruits per plant. Therefore, these high yielding lines can be taken under consideration for selection as varieties. Variation in respect of fruit length and fruit breadth was also observed among the lines. Total soluble solid varied from 3.08 to 3.5 among the lines. Infection of TYLCV at different growth stages showed that 13 lines had tolerance to virus infection. Rest six lines also had low infection rates (1.4 to $2.8 \%$ ).

Table 2. Some quality parameters of 19 segregating tomato lines.

\begin{tabular}{|c|c|c|c|c|c|}
\hline Genotype & $\begin{array}{c}\text { No. of } \\
\text { locule/ fruit }\end{array}$ & Fruit shape & Flesh colour & Firmness & Fleshiness \\
\hline $12-5-3-6-1$ & 2.9 & High round & Red & Good & Good \\
\hline $12-2-1-1-1$ & 3.1 & High round & Light red & Good & Good \\
\hline $12-5-3-3-1$ & 2.9 & Square & Light red & Good & Medium \\
\hline $12-1-1-3-1$ & 3.6 & High round & Yellowish red & Good & Good \\
\hline $12-5-1-1-1$ & 3.6 & High round & Yellowish red & Good & Good \\
\hline $8-1-3-4-1$ & 7.4 & High round & Excellent red & Medium & Medium \\
\hline $8-1-3-4-2$ & 8.5 & Round & Excellent red & Medium & Medium \\
\hline $8-1-3-2-1$ & 7.6 & Round & Excellent red & Good & Good \\
\hline $8-1-3-1-1$ & 7.0 & High round & Excellent red & Poor & Medium \\
\hline $8-1-3-2-2$ & 7.7 & High round & Excellent red & Good & Good \\
\hline $9-2-1-2-1$ & 2.0 & Round & Light red & Good & Good \\
\hline $14-1-1-1-1$ & 2.0 & Round & Light red & Medium & Good \\
\hline $15-3-4-2-1$ & 7.5 & $\begin{array}{l}\text { Slightly } \\
\text { flattened }\end{array}$ & Red & Medium & Medium \\
\hline $15-1-1-2-1$ & 7.0 & Round & Red & Good & Good \\
\hline $15-3-4-6-2$ & 5.8 & $\begin{array}{l}\text { Slightly } \\
\text { flattened }\end{array}$ & Red & Good & Good \\
\hline $15-1-2-1-1$ & 7.0 & $\begin{array}{l}\text { Slightly } \\
\text { flattened }\end{array}$ & Red & Good & Good \\
\hline $15-1-2-2-1$ & 7.8 & $\begin{array}{l}\text { Slightly } \\
\text { flattened }\end{array}$ & Red & Good & Medium \\
\hline $15-1-2-1-2$ & 6.5 & $\begin{array}{l}\text { Slightly } \\
\text { flattened }\end{array}$ & Red & Good & Good \\
\hline $15-3-4-6-1$ & 5.5 & $\begin{array}{l}\text { Slightly } \\
\text { flattened }\end{array}$ & Red & Good & Good \\
\hline
\end{tabular}


Some quality parameters are presented in Table 2. Variation in locule number was observed among the lines. The lines, 12-5-3-6-1, 12-2-1-1-1, 12-5-3$3-1,12-1-1-3-1,12-5-1-1-1,9-2-1-2-1$, and 14-1-1-1-1 had lower number of locules (2 to 3.6) while the rest were multi-loculer in nature and having more than five locules per fruit. Fruit shape also varied among the lines. It was round, high round, slightly flattened or squares. Different flesh colour was also observed in this study. The lines 8-1-3-4-1, 8-1-3-4-2, 8-1-3-2-1, 8-1-3-1-1 and 8-1-3-2-2 had excellent red flesh colour and thus can be considered for processing purpose (AVRDC, 1999). The flesh colour of the other lines were red, light red or yellowish red. Most of the lines had medium to good firmness and fleshiness nature of the fruit.

Table 3. Phenotypic correlation coefficients among yield and yield contributing characters of tomato lines.

\begin{tabular}{l|l|l|l|l|l|l|l}
\hline \multicolumn{1}{c|}{ Trait } & $\begin{array}{c}\text { Plant } \\
\text { height }\end{array}$ & $\begin{array}{c}\text { No. of } \\
\text { fruits/ } \\
\text { plant }\end{array}$ & $\begin{array}{c}\text { Individual } \\
\text { fruit wt }\end{array}$ & $\begin{array}{c}\text { Fruit } \\
\text { length }\end{array}$ & $\begin{array}{c}\text { Fruit } \\
\text { breadth }\end{array}$ & Locule & $\begin{array}{c}\text { Fruit } \\
\text { yield/ } \\
\text { plant }\end{array}$ \\
\hline Plant height & 1.0 & 0.133 & -0.007 & 0.198 & 0.117 & 0.008 & 0.205 \\
No. of fruits/plant & & 1.0 & $-0.807^{* *}$ & -0.241 & $-0.82^{* *}$ & $0.847^{* *}$ & 0.147 \\
Individual fruit wt & & & 1.0 & $0.506^{*}$ & $0.90^{* *}$ & $0.911^{* *}$ & $0.682^{* *}$ \\
Fruit length & & & 1.0 & 0.431 & 0.283 & $0.583^{* *}$ \\
Fruit breadth & & & & 1.0 & $0.844^{*}$ & $0.479^{*}$ \\
Locule & & & & 1.0 & $0.480^{*}$ \\
Fruit yield/plant & & & & & 1.0 \\
\hline
\end{tabular}

* and ** significant at 5 and $1 \%$ level of probability

Phenotypic correlation coefficients (Table 3) analysis showed that there was strong positive correlation between fruit yield per plant and individual fruit weight $\left(\mathrm{r}=682^{* *}\right)$ and fruit yield and fruit length $\left(\mathrm{r}=583^{* *}\right)$. A moderate but significant positive correlation was also observed between fruit yield and locule number and fruit yield and fruit breadth. Islam and Khan (1996) also observed positive and significant correlation between fruit yield per plant and plant height, fruit yield per plant and days to first flower and between fruit number per plant and fruit yield per hectare. The significant association between fruit yield per plant with individual fruit weight, fruit length, locule number, and fruit breadth in the present study indicated that selection for these traits can be effective in bringing about improvement in fruit yield. The character individual fruit weight was positively correlated with fruit length and fruit breadth, but there was a negative correlation between number of fruits per plant. So these traits should be kept in mind during planning any breeding program for improving the trait of individual fruit weight since this trait is largely influenced by fruit yield per plant. However, the lines, 8-1-3-4-1, 8-1-3-1-1, 8-1-3-2-2, 14-1-1-1-1, 15-3-4-2$1,15-1-2-2-1$ and 15-1-2-1-2 produced more than $2.0 \mathrm{~kg}$ of fruits per plant, and can be put into a multi-location trial for further evaluation and recommendation 
as varieties. Again a wide range of variability was found for number of fruits per plant, individual fruit weight, and locule number and thus can further be improved through selection.

\section{References}

Anonymous. 2007. Annual Report, 2006-2007. Olericulture Division, HRC, BARI, Gazipur. pp 125

Anonymous. 2008. Annual Report, 2007-2008. Olericulture Division, HRC, BARI, Gazipur. pp 148

AVRDC. 1998. AVRDC Report 1997. Asian Vegetable Research and Development Centre, Shanhua, Tainan, Taiwan. 191 p.

AVRDC. 1999. ARC Training Report 1998. The 16th Regional Training Course on Vegetable Production and Research. ARC-AVRDC, Thailand. 202 p.

Islam, M.S. and S. Khan. 1996. Plant growth, fruit and seed production of tomatoes as influenced by sowing season and planting pattern. Thai J. Agric. Sci. 29: 531-543.

Kasrawi, M.A., M.A. Suwwan and A. Mansur. 1988. Sources of resistance to tomato yellow leaf curl virus in Lycopersicon species. Euphytica 37: 6 1-64.

Muqit, M. 2006. Management of tomato yellow leaf curl virus (TYLCV) in Bangladesh. Ph.D thesis. Department of Plant Pathology, Bangabandhu Sheikh Mujibur Rabman Agricultural University, Salna, Gazipur. p. 187.

Nakala, M.K. and D.P. Maxwell. 1998. Epidemiology and management of tomato yellow leaf curl disease. In: A. Hadidi, R.K. Khetarpal and H. Koganezawa (Eds). Plant Virus Disease Control. APS press: St. Paul, Minnesota, USA. p. 565-578.

Panse, V. G. and P. V. Sukhatme. 1967. Statistical Method for Agricultural Workers. $2^{\text {nd }}$ Ed. Indian Council of Agricultural Research, New Delhi. pp.381.

Rashid, M.A., S. Ahmad, S. Saha, S.N. Alam and M.A. Rahman. 2006. Production of solanaceous vegetable (in Bengali). Olericulture Division, HRC, BARI, Gazipur. $158 p$. 